\title{
Metal concentrations in common skittering frog (Euphlyctis cyanophlyctis) inhabiting Korang River, Islamabad, Pakistan
}

\author{
Tariq Mahmood*, Irfan Qadir Qadosi, Hira Fatima, Faraz Akrim, Muhammad Rais \\ Department of Wildlife Management, PMAS-Arid Agriculture University, Rawalpindi 46300, Pakistan. \\ *Correspondence: Phone: +92 0321-5105689, Fax: +92 051-9290468, E-mail: tariqjanjua75@uaar.edu.pk
}

Received: 20 January 2016; returned for review: 29 April 2016; accepted 28 July 2016.

The current study investigated metal concentrations $(\mathrm{Zn}, \mathrm{Cd}, \mathrm{Pb}, \mathrm{Mn}$ and $\mathrm{Fe}$ ) in the habitat and body tissues (blood, liver and kidney) of common skittering frog Euphlyctis cyanophlyctis along the Korang River, Islamabad, Pakistan. Samples were collected from three selected contaminated sites and a reference site at four different occasions from October 2010 to March 2012. All studied metals showed elevated levels in river water, as well as in blood, liver and kidneys of frogs from all contaminated sites. Specifically, Mn showed significantly higher levels in all analysed matrices from contaminated sites compared to the reference site. Histological sections of frog livers exposed to elevated metals showed abnormal hepatocytes, while their kidney sections showed discontinuous glomeruli with dead or ruptured cells exhibiting improper shapes with cytoplasmic depositions. This study indicates that frogs inhabiting Korang River are at potential risk of metal toxicity from the environment.

Key words: Dicroglossidae; histology; histopathology; metal bioaccumulation; pollution.

Concentraciones de metales en Euphlyctis cyanophlyctis del río Korang en Islamabad, Paquistán. Se investigaron concentraciones de varios metales $(\mathrm{Zn}, \mathrm{Cd}, \mathrm{Pb}, \mathrm{Mn}$ and $\mathrm{Fe})$ en el hábitat y en tejidos (sangre, hígado y riñones) de la rana Euphlyctis cyanophlyctis a lo largo del río Korang en Islamabad, Paquistán. Se tomaron muestras de tres sitios seleccionados como contaminados y de una localidad de referencia en cuatro ocasiones entre octubre de 2010 y marzo de 2012. Todos los metales analizados mostraron niveles elevados en el agua del río y en la sangre, hígado y riñones de las ranas procedentes de los sitios contaminados. Los niveles de Mn fueron significativamente mayores en lugares contaminados con relación a la localidad de referencia. Los cortes histológicos de hígados de ranas expuestas a metales mostraron hepatocitos anómalos, mientras que las secciones de los riñones presentaban glomérulos discontinuos y células muertas o rotas con formas anómalas y deposiciones citoplasmáticas. Este estudio sugiere que las ranas que habitan en el río Korang están en riesgo de sufrir intoxicaciones a causa de los metales presentes en el medio.

Key words: bioacumulación de metales; contaminación; Dicroglossidae; histología; histopatología.

Metal pollution has an important role in global biodiversity decline (FICKEN \&
Byrne, 2013). In Pakistan, soils, air and water are heavily polluted with different 
metals including mercury (Hg), arsenic $(\mathrm{As})$, lead $(\mathrm{Pb})$, zinc $(\mathrm{Zn})$, manganese $(\mathrm{Mn})$, lithium (Li), cadmium (Cd) and chromium (Cr) (Авваs et al., 2004). Several metals, including those that are essential for life, occur naturally in the water, but their levels must remain within acceptable ranges not to be toxic to aquatic organisms, as recommended by the environmental and health protection agencies (US EPA, 1993; WHO, 1998). Excess concentrations of several metals appear in nullah waters (i.e. water currents flowing at the bottom of steep valleys) from industrial effluents, posing serious threat to biodiversity dependent on such nullah waters. It is estimated that about 90 to $95 \%$ of all domestic sewage and $75 \%$ of all industrial effluents are discharged into surface waters without proper treatment (HINRICHSEN et al., 1997; PANDEY, 2006) resulting in contamination of soil, water and air, and hence threatening human and biodiversity health (Hamidullah et al., 1997; IQbal et al., 1998). Industrial effluents, organic wastes, refuse burnings, transport and solid sludge contain acids, alkalis, sodium chloride and metals ( $\mathrm{Cd}$ and $\mathrm{Cr}$ ), which are released in huge quantities into the nullahs and streams (ZAMAN \& ArA, 2000; Agarwal, 2002; TAHIR \& NASEEM, 2007).

Documented effects of pollutants on amphibians range from lethal to sublethal effects including decreased growth and development, as well as increased frequency of developmental abnormalities, susceptibility to diseases and behavioural alterations (e.g. BRIDGEs, 1999; OrTIz et al., 2004; Relyea, 2005; Griffis-Kyle, 2007; KARRAKer et al., 2008; SHINN et al., 2008; SNOdgrass et al., 2008; Relyea \&
Jones, 2009). Anuran amphibians are particularly susceptible to the uptake of metals because they have highly permeable skin, which allows the rapid absorption of metal ions. Additionally, due to the larval microphagous feeding habit of most species, tadpoles frequently ingest sediment in which metals can accumulate (Hopkins \& Rowe, 2010). Additionally, due to the larval microphagous feeding habit of most species, tadpoles frequently ingest sediment in which heavy metals can accumulate (Hopkins \& Rowe, 2010). Some previously published studies have reported that over one third of the world's amphibians are facing extinction, and that almost half of extant species are experiencing widespread population declines (STUART et al., 2004), and one of the major causes widely implicated in population declines of amphibians is the contamination of freshwater systems with metals derived from industrial and agricultural sources (GrEIG et al., 2010; Hopkins \& Rowe, 2010). Different researchers have attempted to document impacts of metal accumulations under laboratory (Herkovits \& Helguero, 1998; JAmes \& LitTLE, 2003) and field conditions (Demichelis et al., 2001; FlyAKs \& Borkin, 2004; FenogLio et al., 2006), while some other studies have reported deformities, delayed metamorphosis, decreased flight response and altered interactions with predators in amphibians after exposure to metals in the water (CHen et al., 2009; JAMEs \& SEMLiTsCH, 2011; Zocche et al., 2013).

In Pakistan, concentrations of various contaminants including heavy metals in ground and surface water and soil (Yousafzai \& Shakoori, 2008; Shah et al., 2009; Ghumman, 2011; Gilani et al., 2013), 
and in bird feathers (Movalli, 2000; Boncompagni et al., 2003; Bostan et al., 2007) have been assessed, which indicates that metal pollution is an environmental problem in the country. However, in the case of amphibians, although a few studies (KHAN et al., 2003, 2007; KHAN, 2004) have reported decreases in enzymatic activities in frogs after exposure to pesticides, there is a dearth of research pertaining to effects of metals on these animals. The present paper reports a biomonitoring study designed to estimate the concentrations of various metals in habitats (water), and blood samples of common skittering frogs (Euphlyctis cyanophlyctis) inhabiting Korang River (Islamabad, Pakistan) and to investigate the related histological changes in frogs' body tissues (i.e. liver and kidney).

\section{Materials and Methods}

\section{Study area}

The Korang River originates from Murree, upstream the Rawal Lake in Islamabad. The outflow from the lake runs approximately $20 \mathrm{~km}$ before discharging in the Sowan River in Rawalpindi (Fig. 1). This area belongs to the Potohar plateau and has an altitude range from 502 to 609 $\mathrm{m}$. The river water receives sewage and other wastes from the adjoining human dwellings on either side. In addition, there are two small marble factories that also discharge their waste directly into the river water.

Three sampling sites were selected along the river (Fig. 1) for collection of frog specimens and water samples. The

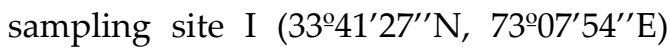
was located near the spillways of Rawal Lake, with a relatively clean water. Sam- pling sites II and III were situated down-

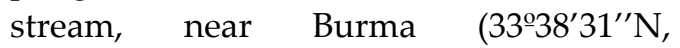
730' $\left.94^{\prime \prime} \mathrm{E}\right)$ and Highway Bridges

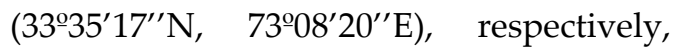
both sites showing visible signs of water pollution such as a dark water colour and a foul smell. The land distance between the selected sampling sites was approximately five kilometres.

The vegetation along the Korang River is of riparian type, consisting mainly of Cynodon dactylon, Euphorbia helioscopia, Malvastrum coromandelianum, Stellaria media, Melilotus indica, Coronopus didymus and Cannabis sativa (Aнмаd et al., 2014).

\section{Sample collection}

Six adult frogs and six water samples from each sampling site were collected on four occasions in October 2010, February 2011, December 2011 and March 2012 (total $\mathrm{N}=24$ ) using pitfall traps as standard technique for frog capture (CAMPBELL \& Christman, 1982; Corn \& Bury, 1990; Heyer et al., 1994) and also by hand picking and using dip nets in the water. For using as control samples in the current study, six samples of water and six frogs were collected from the campus of the PMAS Arid Agriculture University, Rawalpindi, where a couple of temporary, pollutionfree water ponds are found, especially in the rainy season.

Frogs were taken to the laboratory, anaesthetized using chloroform and sacrificed to collect blood by cardiac puncture and body tissue (i.e. liver and kidney). All animal handling and sacrifice was carried out in accordance with the guidelines provided by the Ethics Committee of the University (PMAS-AAUR/2646) and were ap- 
proved by such Committee. In addition, it is pertinent to mention that the species used in the present study has no associated conservation issues.

All solutions were prepared with analytical reagent grade chemicals and distilled water. All plastic and glassware were cleaned by soaking in $2 \mathrm{M} \mathrm{HNO}_{3}$ for $48 \mathrm{~h}$, and rinsed five times with distilled water, and then five times with deionized water prior to use.

\section{Estimation of metal concentrations}

We estimated concentrations of $\mathrm{Zn}, \mathrm{Cd}$, $\mathrm{Pb}, \mathrm{Mn}$ and Fe in the water, blood and tissue samples using atomic absorption spectrophotometry (AASP, Fransion, 1981). To digest the tissues for atomic absorption spectrophotometry, we placed $0.5 \mathrm{~g}$ of tissue in $5 \mathrm{ml}$ nitric acid (69\%) and $0.5 \mathrm{ml}$

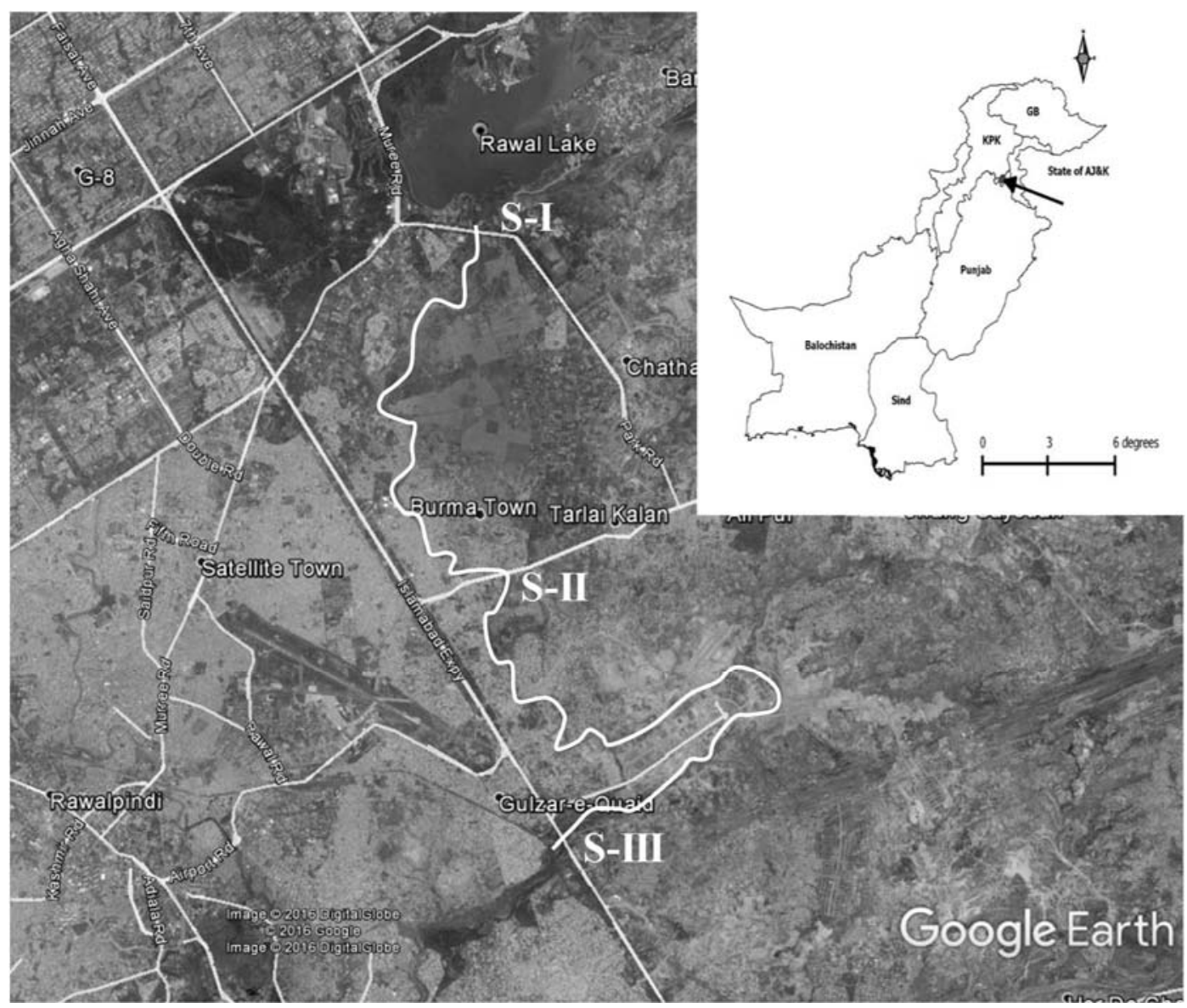

Figure 1: Location of the study area within Pakistan (black arrow in the right top map) and location of the three study sites (S-I, S-II, S-III) along the Korang River (white line) outflowing from Rawal Lake (image downloaded and modified from Google Earth, and published according to the guidelines established by the copyright owner; see Google Permissions at http:// www.google.com/permissions/geoguidelines.html). 
Table 1: Metal Concentrations (Mean \pm SE) in experimental river water, and blood, liver and kidney samples of frogs (Euphlyctis cyanophlyctis) inhabiting Korang River, Islamabad, Pakistan. Asterisks identify groups that were significantly different from reference site according to the Least Significant Difference post-hoc tests $(\mathrm{P}<0.05)$. LoD: limit of detection.

\begin{tabular}{|c|c|c|c|c|c|}
\hline \multirow{2}{*}{ Sample } & \multirow{2}{*}{ Metal } & \multirow{2}{*}{ Reference site } & \multicolumn{3}{|c|}{ Korang River sites } \\
\hline & & & Site I & Site II & Site III \\
\hline \multirow{5}{*}{$\begin{array}{l}\text { Water } \\
(\mu \mathrm{g} / \mathrm{ml})\end{array}$} & $\mathrm{Zn}$ & $0.32 \pm 0.03$ & $0.15 \pm 0.09$ & $0.17 \pm 0.09$ & $0.11 \pm 0.02^{*}$ \\
\hline & $\mathrm{Cd}$ & $0.09 \pm 0.01$ & $0.08 \pm 0.01$ & $0.08 \pm 0.01$ & $0.08 \pm 0.02$ \\
\hline & $\mathrm{Pb}$ & $0.02 \pm 0.01$ & $0.97 \pm 0.35^{*}$ & $1.44 \pm 0.66^{*}$ & $1.41 \pm 0.61^{*}$ \\
\hline & Mn & $0.06 \pm 0.10$ & $0.04 \pm 0.02$ & $0.09 \pm 0.04$ & $0.19 \pm 0.08^{*}$ \\
\hline & $\mathrm{Fe}$ & $0.19 \pm 0.05$ & $0.13 \pm 0.03$ & $0.26 \pm 0.11^{*}$ & $0.36 \pm 0.14^{*}$ \\
\hline \multirow{5}{*}{$\begin{array}{l}\text { Blood } \\
(\mu \mathrm{g} / \mathrm{ml})\end{array}$} & $\mathrm{Zn}$ & $2.40 \pm 0.69$ & $0.58 \pm 0.18$ & $0.92 \pm 0.54$ & $0.46 \pm 0.16$ \\
\hline & $\mathrm{Cd}$ & $0.02 \pm 0.00$ & $0.02 \pm 0.00$ & $<\mathrm{LoD}$ & $0.12 \pm 0.02^{*}$ \\
\hline & $\mathrm{Pb}$ & $<\mathrm{LoD}$ & $<\mathrm{LoD}$ & $0.09 \pm 0.02$ & $0.003 \pm 0.00$ \\
\hline & $\mathrm{Mn}$ & $0.06 \pm 0.02$ & $0.65 \pm 0.17^{*}$ & $0.37 \pm 0.10^{*}$ & $0.55 \pm 0.10^{*}$ \\
\hline & $\mathrm{Fe}$ & $1.90 \pm 0.50$ & $2.30 \pm 0.98^{*}$ & $3.10 \pm 1.04^{*}$ & $2.50 \pm 1.71^{*}$ \\
\hline \multirow{5}{*}{$\begin{array}{l}\text { Liver } \\
(\mu \mathrm{g} / \mathrm{g})\end{array}$} & $\mathrm{Zn}$ & $1.53 \pm 0.75$ & $2.69 \pm 1.02$ & $2.14 \pm 0.64$ & $1.99 \pm 0.83$ \\
\hline & $\mathrm{Cd}$ & $0.06 \pm 0.01$ & $0.12 \pm 0.00$ & $0.05 \pm 0.00$ & $0.16 \pm 0.01^{*}$ \\
\hline & $\mathrm{Pb}$ & $1.37 \pm 0.41$ & $1.26 \pm 0.04$ & $2.71 \pm 0.16$ & $1.58 \pm 0.20$ \\
\hline & $\mathrm{Mn}$ & $0.19 \pm 0.03$ & $0.56 \pm 0.07^{*}$ & $0.42 \pm 0.13^{*}$ & $0.44 \pm 0.12^{*}$ \\
\hline & $\mathrm{Fe}$ & $2.80 \pm 0.8$ & $3.40 \pm 0.14$ & $3.80 \pm 0.97$ & $2.9 \pm 0.84$ \\
\hline \multirow{5}{*}{$\begin{array}{c}\text { Kidney } \\
(\mu \mathrm{g} / \mathrm{g})\end{array}$} & $\mathrm{Zn}$ & $1.45 \pm 0.70$ & $2.46 \pm 0.06^{*}$ & $1.54 \pm 0.87$ & $1.72 \pm 0.08$ \\
\hline & $\mathrm{Cd}$ & $0.02 \pm 0.00$ & $0.15 \pm 0.00$ & $0.08 \pm 0.00$ & $0.09 \pm 0.01$ \\
\hline & $\mathrm{Pb}$ & $0.60 \pm 0.17$ & $0.92 \pm 0.10$ & $0.88 \pm 0.09$ & $0.98 \pm 0.14$ \\
\hline & $\mathrm{Mn}$ & $0.14 \pm 0.02$ & $0.59 \pm 0.12^{*}$ & $0.46 \pm 0.04^{*}$ & $0.50 \pm 0.12^{*}$ \\
\hline & $\mathrm{Fe}$ & $3.41 \pm 0.59$ & $4.53 \pm 0.13$ & $4.87 \pm 0.62$ & $3.99 \pm 0.58$ \\
\hline
\end{tabular}

perchloric acid and left them overnight in the laboratory at room temperature for digestion. Next morning, these samples were heated for complete digestion by using hot plate with magnetic stirrer (HB 502 Bibby) for 20 minutes. Temperature range for heating was $30^{\circ} \mathrm{C}$ to $100^{\circ} \mathrm{C}$. The samples were then filtered and diluted up to $10 \mathrm{ml}$ final volume. Determination of metal concentrations was conducted in an airacetylene flame atomic absorption spectrophotometer GBC 932 Plus (GBC Scientific Equipment, Braeside, Victoria, Australia)
(Fransion, 1981). The water and blood samples were processed and prepared using the same procedure as described above for animal tissues for metal estimation through AASP. Standard dilutions of each metal ( $\mathrm{Zn}, \mathrm{Cd}, \mathrm{Pb}, \mathrm{Mn}$ and $\mathrm{Fe}$ ) were used during analyses to quantify metal concentration in the samples, but no data on recovery were retrieved.

\section{Histological analysis}

The collected liver and kidney tissues of frogs were fixed in $10 \%$ formalin solu- 
tion and processed for standard histological studies. Tissues were embedded in paraffin wax and then tissue sections were cut (5 to $7 \mu \mathrm{m}$ thick) using a rotary Microtome Shandon ${ }^{\circledR}$ Finesse ${ }^{\circledR} 325$ (Thermo Fisher Scientific, Waltham, Massachusetts, USA). The sections were stained with haematoxylin and eosin (BAncroft \& Stevens, 1990; RidDELL, 1996) and analysed directly under a light microscope Olympus BX50 (Olympus, Tokyo, Japan). Although the tissues were cut randomly, an effort was made to get sections from both the periphery and the central part of each organ. At least 20 slides from each organ were prepared for histological analysis.

\section{Statistical procedures}

Data were checked for their normal distribution, and then analyses of the variance (ANOVAs) were run to compare metal levels among study sites. Least significant difference post-hoc tests were conducted for significant ANOVAs to check which specific sites showed differences with regards to controls.

\section{Results}

\section{Metal concentrations in water and tissues}

Among all studied metals, $\mathrm{Pb}, \mathrm{Mn}$ and Fe were the ones showing elevated concentrations in water samples of the river as compared to the control site $\left(\mathrm{Pb}: \mathrm{F}_{3,36}=\right.$ 2.909, $P=0.048 ; \mathrm{Mn}: \mathrm{F}_{3,40}=3.797, P=0.017$; Fe: $\left.\mathrm{F}_{3,40}=3.794, P=0.017\right)$. Among the river sites, $\mathrm{Pb}$ showed significantly high concentrations at the three sites, while levels of Mn were elevated at site III and levels of Fe at sites II and III (Table 1). On the other hand, Zn concentration in river waters was lower than that at the reference site
$\left(\mathrm{F}_{3,60}=8.442, P<0.001\right)$, with a significant difference observed between reference and site II levels of this element (Table 1).

Blood samples of E. cyanophlyctis from the Korang river showed higher concentrations of $\mathrm{Cd}, \mathrm{Mn}$ and Fe than frogs from control site (Table 1). In the cases of Mn and $\mathrm{Fe}$, elevated concentrations compared to control were detected at the three river sites, while increased blood levels of $\mathrm{Cd}$ were observed in frogs from river site II. In addition, although no comparative test was possible in the case of $\mathrm{Pb}$ because of the levels below detection limit at the reference site, detectable concentrations of this element were found at sites II and III. With regards to liver and kidney samples, metal concentrations followed a similar pattern than in blood, with the exception of kidney Zn concentrations, which were higher at river site I than at the reference site, contrarily to the trend observed for blood levels of this element (Table 1). In general, liver and kidney were less sensitive than blood as indicator of inter-site differences. Only Mn in both organs was systematically increased at all river sites compared to control, whereas liver $\mathrm{Cd}$ at site III was also higher than at reference site. On the contrary, the elevated Fe levels observed in blood samples from river frogs were not confirmed with the analyses of liver and kidneys (Table 1).

\section{Histological observations}

When observed under light microscopy, histological sections of livers of E. cyanophlyctis collected from the reference site showed normal continuous hepatocytes with centrally placed nuclei; these cells presented normal shapes with no cytoplas- 

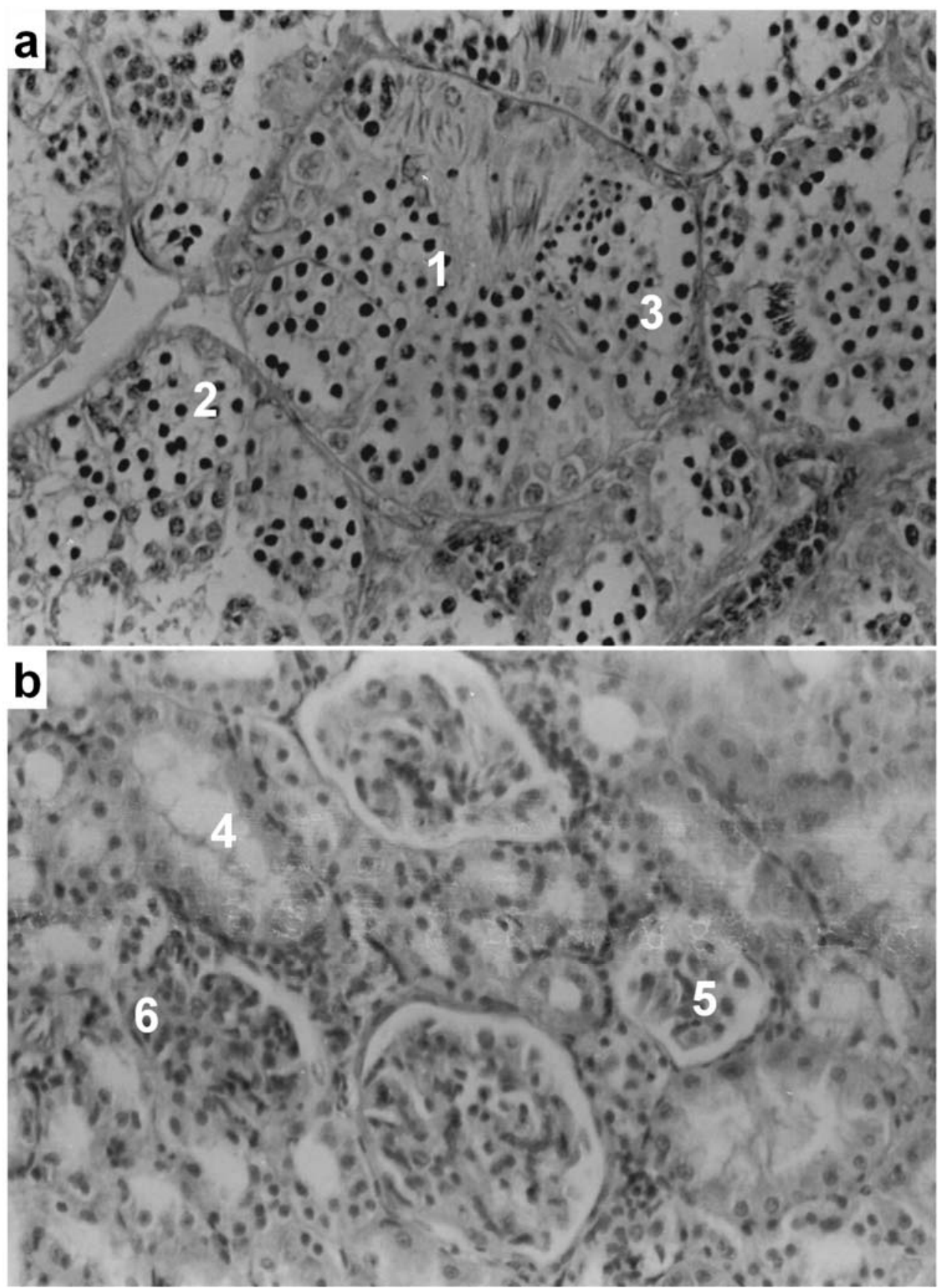

Figure 2: Sections of frog (Euphlyctis cyanophlyctis) livers. (a) Control liver (10X) showing continuous hepatocytes (1), centrally placed nuclei (2), and cells with proper shapes (3) with no cytoplasmic vacuolization. (b) Liver of a frog (10X) captured from river site II showing spacing among cells (4), irregularly placed nuclei (5) with cytoplasmic vacuolization, and cells having irregular shapes (6). 

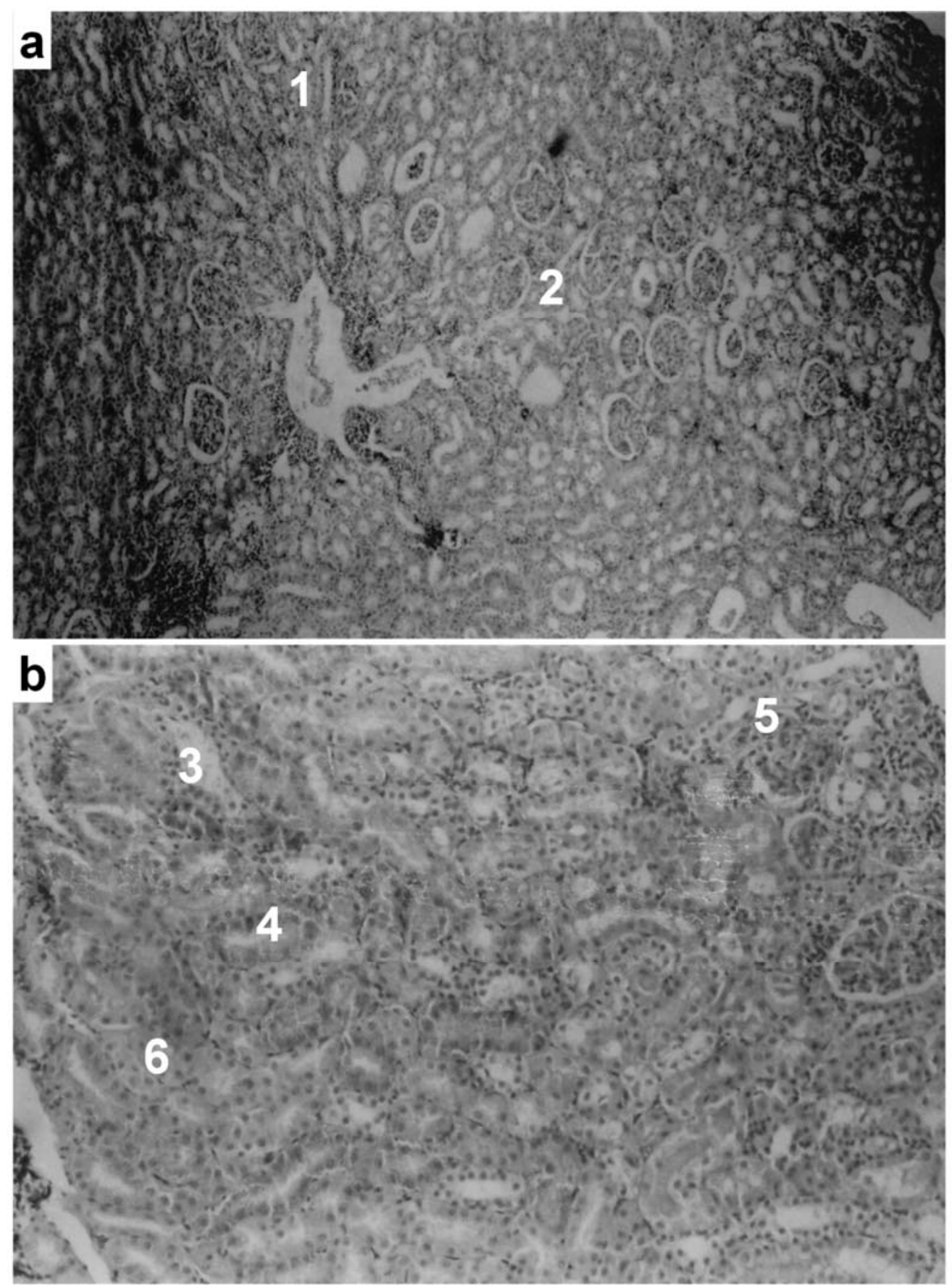

Figure 3: Sections of frog (Euphlyctis cyanophlyctis) kidneys. (a) Control kidney (5X) showing continuous glomeruli (1) and regularly shaped cells (2). (b) Kidney of a frog (5X) captured from site III showing non-continuous glomeruli (3), dead and ruptured cells (4), some depositions in the cells (5) and irregularly shaped cells (6). 
mic vacuolization (Fig. 2a). On the contrary, liver sections of frogs collected from river site II showed irregularly shaped hepatocytes (Fig. 2b). Likewise, histological sections of kidney tissues of frogs collected from sampling site III showed how these kidneys presented discontinuous glomeruli with dead or ruptured cells; kidney cells exhibited improper shapes with cytoplasmic depositions (Fig. 3).

\section{Discussion}

Environmental pollution may result from human activities such as oil spilling or disposal of industrial wastes. It is one of the most important ecological problems affecting developing countries from southern Asia, such as Nepal, India, Bangladesh and Pakistan (Karn \& Harada, 2001), where water pollution is especially severe and critical near urban stretches due to the huge amounts of pollutants discharged by urban activities. In these areas, about 90 to $95 \%$ of all domestic sewage and $75 \%$ of all industrial effluents are discharged into surface waters without any proper treatment (Hinrichsen et al., 1997; Pandey, 2006), resulting in contamination of soil, water and air, and the consequent threat for human, animal and plant health (Hamidullah et al., 1997; IQbal et al., 1998).

Human activities are also behind the increase of metal concentrations to toxic levels in natural aquatic environments; for instance, Owe et al. (1982) demonstrated that urban runoff contributes significantly to the pollution of rivers with Cr. Similarly, LA Zerte (1984) showed that high levels of aluminium (Al) might be the result of acid precipitation, which enhances the mobilisation of $\mathrm{Al}$ from the soil. The main sources of environmental pollution in Pakistan include sewage water, city refuse, fertilisers, pesticides, automobiles, industrial effluents and leather tanning (TAHIR et al., 1998; Ағтав et al., 2000). Huge amounts of solid sludge and effluent water containing acids, alkalis, sodium chloride and heavy metals, mainly $\mathrm{Cd}$ and $\mathrm{Cr}$, are released daily into the nullahs and streams. This wastes directly flow into rivers and eventually into the ocean (Zaman \& Ara, 2000; Tahir \& NAseem, 2007). Metals are released in the environment mostly through industrial effluents, organic wastes, refuse burnings, as well as transport the power generation activities.

Metal pollution in river waters may result in toxic effects on various tissues of animals inhabiting the polluted water site, affecting various functions like general metabolism, hormonal control, growth and reproduction. One of the most vulnerable groups of animals in this respect is amphibians, and especially frogs, since they totally depend upon water for their reproduction and have very permeable skins (Quaranta et al., 2009). Previous studies have described the occurrence of various deformities following exposure of frogs and their larvae to metals (NebeKer et al., 1994).

The results of the present study showed high concentrations of $\mathrm{Pb}, \mathrm{Mn}$ and Fe in river water samples, which could be explained by the discharge of domestic sewage from human dwellings located on both sides of the river. Accordingly, elevated Mn levels were found in blood, liver and kidneys of frogs from river sites compared to control. This suggests that frogs did uptake these metals from their envi- 
ronment (river water) and accumulate them body tissues. However, levels of $\mathrm{Pb}$, although found to be elevated in tissues of animals from the contaminated sites in the river, did not show significant increases when compared to control animals. Fe, as well as $\mathrm{Cd}$ and $\mathrm{Zn}$, were also found to be at higher concentrations in at least one of the analysed tissues (i.e. blood, liver and kidney) of frogs from the river as compared to animals from the reference site.

Metal accumulation by frogs has been previously reported in several studies. For example, livers of Pelophylax ridibundus contained high amounts of copper, cobalt, molybdenum, $\mathrm{Cr}$ and $\mathrm{Cd}$ while carcasses of these animals showed high levels of $\mathrm{Al}$, $\mathrm{Mn}$, nickel, strontium and barium (Loumbourdis \& Wray, 1998). Similarly, Blaustein et al. (2003) showed that metals like $\mathrm{Zn}, \mathrm{Pb}, \mathrm{Cd}$ and $\mathrm{Mn}$ might adversely affect amphibian populations because of accumulation in different body tissues, which ultimately caused abnormal functioning of these tissue cells. Although in the current study we did not investigate the physiological functioning of the animals, the frequent increase of analysed metals in liver and kidneys of frogs from the Korang River, considering control animals as background reference, supports the necessity of conducting further studies to assess potential physiological malfunctions associated with metal accumulation by these frogs.

Some cellular abnormalities were noticeable in the histological sections of body tissues of frogs from the river sites, suggesting that metal uptake could interfere with cellular morphology and physiology. For example, stained sections of liver of $E$. cyanophlyctis from site II revealed irregularly shaped hepatocytes, and those of kidneys from sampling site III showed discontinuous glomeruli having dead or ruptured cells, as well as cells with abnormal shapes and cytoplasmic depositions, as compared to reference tissues. These findings would indicate that metals might alter the levels of ceratin biochemical parameters and cause tissue damage in frogs. Earlier studies conducted on these aspects reported that livers of frogs exposed to $\mathrm{Cd}$ had excessive bile secretion and dilatation of sinusoids (ІкеснUкwu \& AJeH, 2011). Similarly, individuals of Euphlyctis hexadactylus exposed to metals $(\mathrm{Cd}, \mathrm{Cu}, \mathrm{Zn}$ and $\mathrm{Pb}$ ) exhibited marked changes in tissue development, severe bile secretion, haemorrhages and sinusoidal dilatations of liver, as well as distortion of alveolar sacs in the lungs and damaged Bowman's capsules in the kidney (Jayawardena et al., 2013). The potential of toxic effects of metal exposure in E. cyanophlyctis from the Korang River was also supported by the frequent observation of physical and behavioural abnormalities (e.g. asymmetry in limb length and skin coloration, or sluggish behaviour) displayed by frogs captured from this area.

\section{Conclusion}

From the results of the current study, we can conclude that Korang River waters exhibit levels of some metals higher than normal. Aquatic vertebrates, such as frogs, inhabiting this area can take up these metals from the environment, absorb them to the blood and accumulate them in liver and kidneys. The accumulation of these metals at high concentrations in the frog 
body tissues proved toxic for various body functions, leading to histopathological responses in the affected organs. Thus, whereas the common skittering frog is potentially at high risk of metal toxicity at Korang River in the vicinity of Islamabad, further studies are suggested to assess and establish the toxic effects of metal accumulation in these frogs in order to elucidate whether frog survival can be threatened by metal pollution in the study area.

\section{REFERENCES}

Abbas, S.T.; Mehdi, S.M.; Sarfraz, M. \& HassAN, G. (2004). Contents of heavy-metals in waters of nullahs dek, bisharat \& aik, and their effect on soil-health. Science Vision 9: 1-11.

Aftab, Z.; Ali, L.; Khan, A.M.; Robinson, A.C. \& Irshad, I.A. (2000). Industrial Policy and the Environment in Pakistan. Industrial Policy and Environment NC/PAK/97/018, United Nations Industrial Development Organization, Vienna, Austria.

Agarwal, S.K. (2002). Pollution Management, Vol. IV. Heavy Metal Pollution. A.P.H. Publishing Corporation, New Dehli, India.

Ahmad, S.S.; Murtaza, R.; Shabir, R.; Ahmed, N.M. \& SнAH, T.A. (2014). Environmental diversification and spatial variations in riparian vegetation: a case study of Korang River, Islamabad. Pakistan Journal of Botany 46: 1203-1210.

Bancroft, J.D. \& Stevens, A. (1990). Theory and Practice of Histological Techniques, $3^{\text {rd }}$ ed. Churchill Livingstone. Churchill Livingstone, Edinburgh, UK.

Blaustein, A.R.; Romansic, J.M.; Kiesecker, J.M. \& НАтсн, A.C. (2003). Ultraviolet radiation, toxic chemicals and amphibian population declines. Diversity and Distributions 9: 123-140.

Boncompagni, E.; Muhammad, A.; Jabeen, R.; Orvini, E.; Gandini, C.; Sanpera, C.; Ruiz,
X. \& Fasola, M. (2003). Egrets as monitors of trace-metal contamination in wetlands of Pakistan. Archives of Environmental Contamination and Toxicology 45: 399-406.

Bostan, N.; Ashraf, M.; Mumtaz, A. S. \& АнMAD. A. (2007). Diagnosis of heavy metal contamination in agro-ecology of Gujranwala, Pakistan using cattle egret (Bubulcus ibis) as bioindicator. Ecotoxicology 16: 247251.

Bridges, C.M. (1999). Effects of a pesticide on tadpole activity and predator avoidance behavior. Journal of Herpetology 33: 303306.

Campbell, H.W. \& Christman, S.P. (1982). Field techniques for herpetofaunal community analysis, In N.J. Scott, Jr. (ed.). Herpetological Communities. Series: Wildlife Research Reports, vol. 13. Fish and Wildlife Service, US Department of Interior, Washington, D.C., USA.

Chen, T.H.; Gross, J.A. \& Karasov, W.H. (2009). Chronic exposure to pentavalent arsenic of larval leopard frogs (Rana pipiens): bioaccumulation and reduced swimming performance. Ecotoxicology 18: 587-593.

Corn, P.S. \& Bury, R.B. (1990). Sampling Methods for Terrestrial Amphibians and Reptiles. Series: Wildlife-Habitat Relationships: Sampling Procedures for Pacific Northwest Vertebrates (A.B. Carey \& L.F. Ruggiero, eds.). General 'Technical Report PNW-GTR-256, USDA Forest Service, Pacific Northwest Research Station, Portland, Oregon, USA.

Demichelis, S.O.; de la Torre, F.R.; Ferrari, L.; García, M.E. \& SAlibián, A. (2001). Tadpoles assay: its application to a water toxicity assessment of a polluted urban river. Environmental Monitoring and Assessment 68: 63-73.

Fenoglio, C.; Grosso, A.; Boncompagni, E.; Milanesi, G.; Gandini, C. \& Barni, S. (2006). Morphofunctional evidence of changes in principal and mitochondria-rich cells in the epidermis of the frog Rana kl. esculenta living in a polluted habitat. Archives of 
Environmental Contamination and Toxicology 51: 690-702.

Ficken, K.L.G. \& Byrne, P.G. (2013). Heavy metal pollution negatively correlates with anuran species richness and distribution in south-eastern Australia. Austral Ecology 38: 523-533.

FLyAKS, N.L. \& Borkin, L.J. (2004). Morphological abnormalities and heavy metal concentrations in anurans of contaminated areas, eastern Ukraine. Applied Herpetology 1: 229-264.

Fransion, M.A. (1981). Standard Methods for the Examination of Water and Wastewater, $15^{\text {th }} \mathrm{ed}$. American Public Health Association, the American Water Works Association, and the Water Environment Federation (WEF), Washington, D.C., USA.

Ghumman, A.R. (2011). Assessment of water quality of Rawal Lake by long-time monitoring. Environmental Monitoring and Assessment 180: 115-126.

Gilani, S.R.; Mahmood, Z.; Hussain, M.; Baig, Y.; Aвbas, Z. \& Batool, S. (2013). A Study of Drinking Water of Industrial Area of Sheikhupura with Special Concern to Arsenic, Manganese and Chromium. Pakistan Journal of Engineering and Applied Sciences 13: 118-126.

Greig H.S.; Niyogi D.K.; Hogsden K.L.; JellyMAN P.G. \& Harding J.S. (2010). Heavy metals: confounding factors in the response of New Zealand freshwater fish assemblages to natural and anthropogenic acidity. Science of the Total Environment 408: 3240-3250.

Griffis-Kyle K L. (2007). Sublethal effects of nitrite on eastern tiger salamander (Ambystoma tigrinum tigrinum) and wood frog (Rana sylvatica) embryos and larvae: implications for field populations. Aquatic Ecology 41: 119-127.

Hamidullah, S.; Saifullah \& SHah, M.T. (1997). Heavy metal pollution in the eastern part of Peshawar metropolis, north Pakistan. In J. Hanif \& M.I. Hanif (eds.) Environmental Pollution. Proceedings of the National Symposi- um on Modern Trends in Contemporary Chemistry. Pakistan Atomic Energy Commission, Islamabad, Pakistan, pp. 65-73.

Herkovits, J. \& Helguero, L.A. (1998). Copper toxicity and copper-zinc interactions in amphibian embryos. Science of the Total Environment 221: 1-10.

Heyer, W.R..; Donnelly, M.A.; McDiarmid, R.W.; HAyeK, L.-A.C. \& Foster, M.S. (1994). Measuring and Monitoring Biological Diversity. Standard Methods for Amphibians. Smithsonian Institution, Washington, D.C., USA

Hinrichsen, D.; Robey, B. \& Upadhyay, U.D. (1997). Solutions for a Water-Short World, Population Reports. Johns Hopkins School of Public Health, Population Information Program, Baltimore, Maryland, USA.

Hopkins, W. \& Rowe, C. (2010). Interdisciplinary and hierarchical approaches for studying the effects of metals and metalloids on amphibians, In D.W. Sparling, G. Linder, C.A. Bishop \& S.K. Krest (eds.) Ecotoxicology of Amphibians and Reptiles, $2^{\text {nd }}$ ed. CRC Press, Boca Raton, Florida, USA, pp. 325336.

Ікесникwu, E.L. \& AJeH, E.A. (2011). Histopathological alterations in the liver and lungs of Hoplobatrachus occipitalis exposed to sub lethal concentrations of cadmium. Australian Journal of Basic and Applied Sciences 5: 1062-1068.

Iqbal, M. Z.; Sherwani, A.K. \& Shafiq, M. (1998). Vegetation characteristics and trace metals $(\mathrm{Cu}, \mathrm{Zn}$ and $\mathrm{Pb})$ in soils along the super highways near Karachi, Pakistan. Studia Botanica Hungarica 29: 79-86.

JAmes, S.M. \& LitTLE, E.E. (2003). The effects of chromic cadmium exposure on American toad (Bufo americanus) tadpoles. Environmental Toxicology and Chemistry 22: 377-380.

James, S.M. \& SemLitsch, R.D. (2011). Terrestrial performance of juvenile frogs in two habitat types after chronic larval exposure to a contaminant. Journal of Herpetology 45: 186194.

Jayawardena, U.A.; Wickramasinghe, D.D.; 
Ratnasooriya, W.D. \& Udagama, P.V. (2013). Heavy metal induced toxicity of the Indian green frog, Euphlyctis hexadactylus (Ranidae), in the Bellanwila-Attidiya sanctuary, In Proceedings of Annual Research Symposium. University of Colombo, Colombo, Sri Lanka, p. 190.

KarN, S.K. \& Harada, H. (2001). Surface water pollution in three urban territories of Nepal, India, and Bangladesh. Environmental Management 28: 483-496.

Karraker, N.E.; Gibbs, J.P.\& Vonesh, J.R. (2008). Impacts of road deicing salt on the demography of vernal pool-breeding amphibians. Ecological Applications 18: 724-734.

KHAN, M.Z. (2004). Effect of pesticides on amphibians and reptiles. Journal of Experimental Zoology, India 7: 39- 47.

Khan, M.Z.; Maria, Z. \& Fatima, F. (2003). Effects of lambda cyhalothrin (pyrethroid) and monocrotophos (organophosphate) on cholinesterase activity in liver, kidney and brain of Rana cyanophlyctis. Korean Journal of Biological Sciences 7: 165-168.

Khan, M.Z.; Rais, M. And Yasmeen, G. (2007). Inhibitory effects on cholinesterase activity produced by the two different pesticides on brain, liver and kidney of Euphlyctis cyanophlyctis. Journal of Experimental Zoology, India 10: 89-93.

Loumbourdis, N.S. \& Wray, D. (1998). Heavymetal concentration in the frog Rana ridibunda from a small river of Macedonia, northern Greece. Environment International 24: 427-431.

Movalli, P.A. (2000). Heavy metal and other residues in feathers of laggar falcon Falco biarmicus jugger from six districts of Pakistan. Environmental Pollution 109: 267-275.

Nebeker, A.V.; Schuytema, G.S. \& Ott S.L. (1994). Effects of cadmium on limb regeneration in the Northwestern salamander Ambystoma gracile. Archives of Environmental Contaminants and Toxicology 27: 318-322.

Ortiz, M.E.; Marco, A; Saiz, N.I. \& Lizana, M. (2004). Impact of ammonium nitrate on growth and survival of six European amphibians. Archives of Environmental Contaminants and Toxicology 47: 234-239.

Owe, M.; Craul, P.J. \& Halverson, H.G. (1982). Contaminant levels in precipitation and urban surface runoff. Water Resources Bulletin 18: 863-868.

PANDEY, S. (2006). Water pollution and health. Kathmandu University Medical Journal 4: 128134.

Quaranta, A.; Bellantuono, V.; Cassano, G. \& Lippe, C. (2009). Why amphibians are more sensitive than mammals to xenobiotics. Plos ONE 4: e7699.

RelyeA, R.A. (2005). The lethal impacts of Roundup and predatory stress on six species of North American tadpoles. Archives of Environmental Contamination and Toxicology 48: 351-357.

RelyeA, R.A. \& Jones, D.K. (2009). The toxicity of Roundup Original Max® to 13 species of larval amphibians. Environmental Toxicology and Chemistry 28: 2004-2008.

Riddell, C. (1996). Avian Histopathology, $2^{\text {nd }}$ ed. American Association of Avian Pathologists, Kennett Square, Pennsylvania, USA.

Shah, A.Q.; Kazi, T.G.; Arain, M.B.; Baig, J.A.; Afridi, H.I.; Kandhro, G.A.; Khan, S. \& Jamali, M.K. (2009). Hazardous impact of arsenic on tissues of same fish species collected from two ecosystem. Journal of Hazardous Materials 167: 511-515.

Shinn, C.; Marco, A. \& Serrano, L. (2008). Inter - and intra-specific variation on sensitivity of larval amphibians to nitrite. Chemosphere 71: 507-514.

Snodgrass, J.W.; Casey, R.E.; Joseph, D. \& SiMON, J.A. (2008). Microcosm investigations of stormwater pond sediment toxicity to embryonic and larval amphibians: Variation in sensitivity among species. Environmental Pollution 154: 291-297.

Stuart, S.N.; Chanson, J.S.; Cox, N.A.; Young, B.E.; Rodrigues, A.S.L.; Fischman, D.L.; WALLER, R.W. (2004). Status and trends of 
amphibian declines and extinctions worldwide. Science 306: 1783-1786.

TAhir, S.S. \& NASEem, R. (2007). Removal of Cr (III) from tannery wastewater by adsorption onto bentonite clay. Separation and Purification Technology 53: 312-321.

Tahir, M.A.; Chandio, B.A.; Abdullah, M. \& RAshid, A. (1998). Drinking Water Quality Monitoring in the Rural Areas of Rawalpindi. National Workshop on Quality of Drinking Water. March 7, 1998. Pakistan Council of Research in Water Resources, Islamabad, Pakistan.

US EPA (1993). Office of Water Policy and Technical Guidance on Interpretation and Implementation of Aquatic Life Metals Criteria. US EPA Office of Water Policy, Washington, D.C., USA.

WHO (1998) Guidelines for Drinking-Water Qual- ity, $2^{\text {nd }}$ ed. Vol. 2 - Health Criteria and Other Supporting Information - Addendum. World Health Organization, Geneva, Switzerland.

Yousafzai, A.M. \& Shakoori, A.R. (2008). Heavy metal accumulation in the gills of an endangered south Asian freshwater fish as an indicator of aquatic pollution. Pakistan Journal of Zoology 40: 423-430.

Zaman, A. \& ARA, I. (2000). Rising urbanization in Pakistan, some facts and suggestions. The Journal NIPA 7: 31-46.

Zocche, J.J.; Damiani, A.P.; Hainzenreder, G.; Mendonça, R.A.; Peres, P.B.; dos Santos, C.E.I.; Debastiani, R.; Dias, J.F. \& DE AndraDE, V.M. (2013). Assessment of heavy metal content and DNA damage in Hypsiboas faber (anuran amphibian) in coal open-casting mine. Environmental Toxicology and Pharmacology 36: 194-201. 